\title{
Study on the role and efficacy of Triphala Ghrita Aschyotan in Vataj Abhishyanda w.r.t Allergic Conjunctivitis
}

\author{
Research Article
}

\section{Pravin M Bhat ${ }^{{ }^{*}}$}

1. Assistant Professor, Department of Shalakyatantra,

Sumatibhai Shah Ayurved Mahavidyalay, Hadapsar, Pune-28.

\begin{abstract}
Allergic conjunctivitis is a common ophthalmic problem predominantly affecting the outdoor workers. The eyes are exposed to different environmental factors. The eye and eyelids are very common sites for allergic reactions. About $50 \%$ of conjunctivitis seen by primary physicians is allergic in nature. Vataj Abhishyanda is a clinical entity which can be correlated with allergic conjunctivitis. Triphala Ghrita A schyotan helps to relieve the symptoms of Vataj Abhishyand w.r.t allergic conjunctivitis. Triphala Ghrita is a Vyadhi Pratyanik Dravya and helpful in topical eye allergies. Aim: To study the role and efficacy of Triphala Ghrita Aschyotan in Vataj Abhishyanda w.r. t. allergic conjunctivitis. Materials and Method: A total 60 patients of the age group 15-60 years presenting with signs and symptoms of Vataj Abhishyanda w.r.t allergic conjunctivitis were selected randomly from OPD of the department of Shalakyatantra, Government Ayurved College, Nanded (M.S.) within inclusion criteria and were treated in two groups. The 30 patients of trial group were treated with Triphala Ghrita A schyotana and patients of control group in similar number were subjected to Ketotifen Fumarate eye drop. Results: The trial drug Triphala Ghrita is equally effective as compared to Ketotifen eye drop. Trial drug provided more relief in symptoms like Sangharsha (Itching of eyes), which is the parameter of efficacy. Conclusion:Triphala Ghrita Aschyotan is an effective, safe and potent treatment of Vataj Abhishyanda w.r.t allergic conjunctivitis.
\end{abstract}

Keywords: Allergic Conjunctivitis, Vataj Abhishyanda, Triphala Ghrita, Aschyotana, Ketotifen Fumarate

\section{Introduction}

Ayurveda, the ancient science of India has described the importance of an eye, without which a life is miserable. Ayurveda allocates prime place to sense organs, has recognized that among all sense organs, organ of sight is the greatest gift of God and it is our duty to protect and preserve the eyes. The eye is one of the most delicate organ of the body and any sort of symptom make all of us running to the ophthalmologist. This vital organ is exposed to different environmental factors. The eye and eyelids are very common sites for allergic reactions. About $50 \%$ of conjunctivitis seen by primary physicians is allergic in nature.

Sushruta has described the 76 types of eye diseases in his classical text 'Sushruta Samhita'. These eye diseases were classified according to the structures affected in the eye. These diseases are more or less comparable with modern eye diseases. One group of eye diseases known as 'Sarvagata Roga' includes the Netrabhishyanda. Netrabhishyanda is explained under the heading 'Sarvagata Roga' because all the eye disease under this heading are occupying most of the part of the eyeball like Mandala, Sandhi and Patala. Out

*Corresponding Author:

\section{Pravin M Bhat}

Assistant Professor,

Department of Shalakyatantra,

Sumatibhai Shah Ayurved Mahavidyalay,

Hadapsar, Pune-28,

E-mail: vdpravin82@gmail.com

Mobile - +91-9860233173 of all these diseases Netrabhishyanda got tremendous importance because it acts as 'Root Cause' for almost all affections of the eyeball (1). Therefore a wise clinician should treat a case of developing Abhishyanda promptly for the benefit of the patient.

The symptomatology of Vataj Abhishyanda is itching and grittiness of the eyes, foreign body and pricking sensation of eyes, watering, congestion, dryness of eyes, mild lid edema, scanty discharge from eyes, numbness in and around the eye, etc (2). Patients suffering from Vataj Abhishyanda are very commonly found in O.P.D. Hence it has been decided to select Vataj A bhishyanda for the study. Vataj Abhishyanda can be correlated with simple allergic conjunctivitis.

Switching over back to modern, seasonal allergic conjunctivitis and perennial allergic conjunctivitis accounts for 66 to $90 \%$ of all cases of allergic eye diseases (3). Ocular allergy beyond being annoying, may get vary disabling and this can lead to serious physical and physiological discomfort, as well as to significant costs in terms of medical care. The management of ocular allergic reaction is primarily aimed at reducing symptomatology and quelling any significant inflammation so this disease was selected to treat with the Ayurvedic line of treatment.

Kriyakalpa is the only field of Ayurvedic ophthalmology which has the potential to combat to the suffering humanity and Aschyotan is one of the Kriyakalpa mentioned by Acharya Sushruta as a local treatment of eye diseases (4). It relieves the symptoms like itching, pain, hyperaemia, FB sensation, etc. and hence it is useful in all types of Netraroga including 
Vataj Abhishyanda. For the treatment of Vataj Abhishyanda there are so many preparations of Vataghna and Chakshushya Dravyas mentioned in different Samhitas by Acharya. Amongst all of them, Sharangdhara has quoted Triphala as drug of choice to treat effectively for Abhishyanda and all types of attributes (5). Gayadasacharya stated that Triphala Ghrita is Vyadhipratyanik Dravya (6).Triphala and Ghrita are the Chakshushya Dravya (i.e.beneficial for eyes). These Chakshushya Dravyas by its action nourishes the eyes and gives Bala to the most vital Indriya i.e. Chakshurendriya. Triphala was mentioned repeatedly in different compound preparations by Acharya. So Triphala Ghrita decided for study.

Now coming to the modern line of treatment for allergic conjunctivitis which is conservative and symptomatic includes antihistamines, mast cell stabilizers, steroids and NSAIDs. Complete avoidance of allergens exposure may be difficult for many patients. Cold compresses can offer temporary relief. Topical vasoconstrictors with or without antihistamines may provide quick symptoms when the medication is abruptly discontinued. Steroids cause secondary glaucoma and cataract. The artificial tear substitutes and lubricants have short duration of action and develop sensitivity due to toxicity of preservatives in the medicine. The use of preservative free drugs is very costly and many time patients ignore the prescribed treatment. Considering all the lacunas of established treatment and increased prevalent rate of disease due to changing lifestyle it is necessary to look for the alternative therapy which is safe, cheap, easily available and more effective in allergic conjunctivitis. Hence the clinical trial was designed with Triphala Ghrita Aschyotan in Vataj Abhishyanda w.r.t. allergic conjunctivitis

\section{Aim}

To study the role and efficacy of Triphala Ghrita Aschyotan in Vataj Abhishyanda w.r. t. allergic conjunctivitis.

\section{Objective}

i) To study the effect of Triphala Ghrita A schyotan in comparison with Conventional modern treatment of allergic conjunctivitis w.r.t. Vataj Abhishyanda.

ii) To avoid complications of the disease.

iii) To prescribe comparatively cheap and easily available preparation in patient's interest.

\section{Materials and Methods}

A total 60 patients of the age group 15-60 years presenting with signs and symptoms of Vataj Abhishyanda w.r.t allergic conjunctivitis were selected randomly from OPD of the department of Shalakyatantra, Government Ayurved College, Nanded (M.S) within inclusion criteria and were treated in two groups. The 30 patients of trial group were treated with Triphala Ghrita Aschyotana and patients of control group in similar number were subjected to Ketotifen Fumarate eye drop.

\section{Inclusion criteria}

Patients presenting signs and symptoms of Vataj Abhishyanda w.r.t allergic conjunctivitis like itching of eyes, irritation and FB sensation, dryness of eyes, congestion of eyes i.e. redness.

Patients having excessive outdoor work and which are exposed to allergens and the other environmental factors.

Patients of either sex were included in study.

\section{Criteria for diagnosis}

- The patients were interrogated and examined in accordance with proforma. Personal history and family history, general, routine and systemic examinations were carried out to rule out other systemic diseases.

- Examination of visual acuity

- Examination of absolute eosinophil count in tear.

\section{Exclusion Criteria}

- Patients not willing for trial and follow up.

- Patients having viral and bacterial conjunctivitis.

- Patients suffering from vernal keratoconjunctivitis, Atopic keratoconjunctivitis, Giant papillary conjunctivitis.

- Patients having complicated eye diseases and trachoma, chalazion, stye, pterygium, dacryocystitis, trichiasis, etc.

- Patients suffering from corneal opacity, ulcers.

- Patients suffering from systemic disease like HTN, DM, TB, etc.

\section{Parameters for assessment}

Patients fulfilling the diagnostic criteria were taken for analysis by opting following assessment criteria:

- Absolute eosinophil in tear- Present or absent

The following symptoms were given score as below:

- Sangharsh (i.e. itching of eyes):

- Absent (No itching)

- Mild (Itching on exposure)

$-1$

- Moderate (Itching during work)

$-2$

- Severe (Itching all time)

- Nistodana (i.e. irritation and foreign body sensation of eyes):

- Absent (No irritation and FB Sensation) - 0

- Mild (Irritation on exposure) - 1

- Moderate (Irritation during work) - 2

- Severe (Irritation at rest)

- Vishushkabhava (i.e. Dryness of eyes) :

This parameter was decided on the basis of Schirmer's test.

- Absent (20 - $35 \mathrm{~mm})$

- Mild (15 - $20 \mathrm{~mm})$

- Moderate (5 - $15 \mathrm{~mm})$

$-1$

- Severe $(<5 \mathrm{~mm})$

- Raga (i.e. Congestion of eyes):

- Absent (no congestion)

- Mild (Only hyperaemia of conjunctiva) - 1 
- Moderate (Congestion without chemosis of eyes) $-2$

- Severe (Congestion with chemosis of eyes) -3

The graded values were later totally and individually scored and assessed statistically to find out the rate of effect of treatment. The age, sex, occupation, habitat wise distribution of patients with socioeconomic status was also recorded and assessed statistically.

The effect of treatment in each group was assessed separately by analyzing the pre treatment and post treatment data, scores and values. The effect of KetotifenFumarate eye drop was assessed and analyzed statistically. The comparison of the effect of therapy of two groups done by applying Chi Square test.

\section{Ingredients of drug for trial group: (7)}
1. Triphala Kalka : 1 Pala (40 gm)
2. Triphala Kwatha : 64 Tola $(640 \mathrm{ml})$
3. Goghrita
4. Godugdha
: 1/2 Prastha $(320 \mathrm{gm})$
: Quantity same as Kwatha (640 ml)

All the above ingredients are taken into utensils along with stirrer and kept on gas stove or burner. The above mixture is heated till "Snehasiddhi Lakshana" appears in mixture or $320 \mathrm{ml}$ of Ghrita remains in utensil. day.

Dose: A dose of 2 drops two times a day for 15

Antihistamine and mast cell stabilizer- Ketotifen eye drop i.e. Ketotifen Fumarate.

Dose: A dose of 2 drops two times a day for 15 day.

\section{Observations}

A majority of patients $(41.66 \%)$ were reported in age group of $15-25$ yrs followed by $30 \%$ in the age group of 26-35yrs. The observed M: F ratio was 1.60:1. The outdoor workers were $36.67 \%$ as consideration with occupation. The habitat wise distribution of patients shows $51.67 \%$ cases from urban and $48.33 \%$ cases from rural area from both groups. The higher incidence of patients was found in 5-8 months chronicity i.e. 24 cases $(40 \%)$. Considering recurrence only 10 patients have given follow up for recurrence, out of them 3 patients were found recurrence in experimental group.7 patients from control group have given follow up for recurrence, out of them 3 were found recurrence. It may be exposure to the same allergens.

\section{Results}

By statistical analysis, it was proved that, Sangharsha (i.e. itching sensation of eyes), Nistodana (i.e. irritation and foreign body sensation of eyes) and Raag (i.e. Congestion of eyes) were improved in both groups. Paired t-test was significant in both groups $(\mathrm{P}<0.05)$. When unpaired t-test was applied for above symptoms, it was highly significant in Sangharsha (i.e. itching sensation of eyes) and Raag (i.e. Congestion of eyes) symptoms which indicates that the trial drug was more effective in both symptoms than control drug and unpaired t-test was insignificant for Nistodana (i.e. irritation and foreign body sensation of eyes) indicates that the trial drug and control drugs are equally effective in FB sensation and irritation of eyes.

In case of Vishuskabhava symptom in all patients cold lacrimation is too much that the Schirmer's test was negative in every patient. Dryness can only be a symptom felt by patient which makes ocular movements difficult. It merely Vishushkabhava means absence of mucoid discharge and not the dryness of eyes.

The limitations of the study are mainly the investigational parameter. The tests regarding the diagnosis of allergic eye diseases are costly like $\operatorname{IgE}$ count in tear, skin prick test. Also the eosinophil to come in smear it needs vigorous scraping of conjunctiva. So this thing needs careful as well as skillful efforts. The other tests are performed in big hospitals only. But to diagnose an allergic eye disease these test are used at limited extent and rely more on history. So the eosinophil parameter was not fulfilled in this in this study and it remains a challenge for the future researchers in Ayurveda.

In experimental group 13 patients were cured, 10 patients were relieved and 7 patients were not cured. In control group 7 patients were cured, 13 patients relieved and 10 patients were not cured. By applying $\chi 2$ test to this it was summarized that both the treatments are effective in Vataj Abhishyanda w.r.t. allergic conjunctivitis. But the experimental group show good efficacy in all 3 symptoms. If we take the large sample the $\chi 2$ can be significant at $0.05 \%$ level.

The parameter of efficacy was Sangharsha i.e itching sensation of eyes and trial drug shows good results in this symptom than control drug. Also $\chi 2$ test to this symptom also comes significant. Hence the trial drug Triphala Ghrita Aschyotan was effective and its role in Vataj Abhishyanda w.r .t. allergic conjunctivits.

Table 1: Effect of therapy on Sangharsha i.e. itching of eyes

\begin{tabular}{|l|l|l|}
\hline $\begin{array}{l}\text { Follow up in } \\
\text { days }\end{array}$ & $\begin{array}{l}\text { Mean of } \\
\text { experimental } \\
\text { group }\end{array}$ & $\begin{array}{l}\text { Mean of } \\
\text { control group }\end{array}$ \\
\hline 0 & 2.90 & 2.76 \\
\hline 5 & 1.85 & 2.03 \\
\hline 10 & 1.23 & 1.36 \\
\hline 15 & 0.30 & 0.56 \\
\hline $\begin{array}{l}\text { Difference in } \\
\text { B.T and A.T }\end{array}$ & 2.60 & 2.20 \\
\hline
\end{tabular}

Table 2: Effect of therapy on Nistodana i.e. irritation of eyes

\begin{tabular}{|l|l|l|}
\hline $\begin{array}{l}\text { Follow up in } \\
\text { days }\end{array}$ & $\begin{array}{l}\text { Mean of } \\
\text { experimental } \\
\text { group }\end{array}$ & $\begin{array}{l}\text { Mean of } \\
\text { control group }\end{array}$ \\
\hline 0 & 2.56 & 2.53 \\
\hline 5 & 1.7 & 2.07 \\
\hline 10 & 1.07 & 1.13 \\
\hline 15 & 0.27 & 0.33 \\
\hline $\begin{array}{l}\text { Difference in } \\
\text { B.T and A.T }\end{array}$ & 2.29 & 2.2 \\
\hline
\end{tabular}


Pravin M Bhat, Effect of Triphala ghrita aschyton in Vataja abhishyanda w.r.t Allergic conjunctivits

Table 3: Effect of therapy in Raag i.e. congestion of eyes

\begin{tabular}{|l|l|l|}
\hline Follow up in days & Mean of experimental group & Mean of control group \\
\hline 0 & 2.76 & 2.6 \\
\hline 5 & 1.80 & 2.03 \\
\hline 10 & 1.07 & 1.16 \\
\hline 15 & 0.30 & 0.50 \\
\hline $\begin{array}{l}\text { Difference in } \\
\text { B.T and A.T }\end{array}$ & 2.46 & 2.1 \\
\hline
\end{tabular}

Table 4: Showing effect of treatment on Signs and symptoms of Experimental Group

\begin{tabular}{|l|l|l|l|l|l|l|l|}
\hline Sr.no & $\begin{array}{l}\text { Symptoms and } \\
\text { sign }\end{array}$ & N & M.D & S.D & S.E & T & P \\
\hline 1 & Sangharsha & 30 & 2.60 & 0.52 & 0.095 & 27.36 & $\mathrm{P}<0.05$ \\
\hline 2 & Nistodana & 30 & 2.29 & 0.52 & 0.095 & 24.10 & $\mathrm{P}<0.05$ \\
\hline 3 & Raag & 30 & 2.46 & 0.51 & 0.093 & 26.45 & $\mathrm{P}<0.05$ \\
\hline
\end{tabular}

In case of all symptoms $\mathrm{P}<0.05\left(\mathrm{t}_{\mathrm{tab}}=2.05\right)$, hence the test is significant. That means the drug therapy Triphala Ghrita Aschyotan is effective in Vataj Abhishyanda w.r.t allergic conjunctivitis.

Table 5: Showing effect of treatment on signs and symptoms of Control Group

\begin{tabular}{|l|l|l|l|l|l|l|l|}
\hline Sr.no & $\begin{array}{l}\text { Symptoms } \\
\text { and signs }\end{array}$ & $\mathrm{N}$ & M.D & S.D & S.E & T & $\mathrm{P}$ \\
\hline 1 & Sangharsha & 30 & 2.2 & 0.63 & 0.1156 & 19.03 & $\mathrm{P}<0.05$ \\
\hline 2 & Nistodana & 30 & 2.2 & 0.72 & 0.1316 & 16.71 & $\mathrm{P}<0.05$ \\
\hline 3 & Raag & 30 & 2.1 & 0.58 & 0.1068 & 19.66 & $\mathrm{P}<0.05$ \\
\hline
\end{tabular}

In case of all symptoms $\mathrm{P}<0.05\left(\mathrm{t}_{\mathrm{tab}}=2.05\right)$, hence the test is significant. That means the control therapy Ketotifen Fumarate is effective in Vataj Abhishyanda w.r.t Allergic conjunctivitis.

Applying unpaired t- test to compare the results achieved by both treatments are:

Table 6: In case of Sangharsha i.e. itching sensation of eyes

\begin{tabular}{|l|l|l|l|l|l|l|}
\hline \multicolumn{2}{|l|}{ Experimental Group } & \multicolumn{2}{l|}{ Control Group } & S.E & T & P \\
\cline { 1 - 3 } Mean & S.D & Mean & S.D & & & \\
\hline 2.6 & 0.52 & 2.2 & 0.63 & 0.1274 & 3.14 & $\mathrm{P}<0.05$ \\
\hline
\end{tabular}

$\mathrm{t}$ - Calculated is 3.14 and $\mathrm{t}-$ table is 2.00 , i.e. $\mathrm{t}_{\mathrm{tab}}<\mathrm{t}_{\mathrm{cal}}$, hence $\mathrm{t}$ - test is significant and indicates that here the drug Triphala Ghrita's effect is more than control drug Ketotifen on itching sensation.

Table 7: In case of Nistodana i.e. Foreign Body and pricking sensation of eyes

\begin{tabular}{|c|c|c|c|c|c|c|}
\hline \multicolumn{2}{|c|}{ Experimental Group } & \multicolumn{2}{|c|}{ Control Group } & \multirow[t]{2}{*}{$\begin{array}{l}\text { S.E } \\
\end{array}$} & \multirow[t]{2}{*}{$\mathrm{T}$} & \multirow[t]{2}{*}{$P$} \\
\hline Mean & $\begin{array}{l}\text { S.D } \\
\end{array}$ & Mean & $\begin{array}{l}\text { S.D } \\
\end{array}$ & & & \\
\hline 2.29 & 0.52 & 2.20 & 0.72 & 0.1404 & 0.64 & $\mathrm{P}>0.05$ \\
\hline
\end{tabular}

Here $t_{c a l}$ is 0.64 and $t_{\text {tab }}$ is 2, i.e. $t_{\text {tab }}>t_{c a l}$. Hence $t$-test is insignificant indicates that there is no significant difference of effect on Foreign Body and pricking sensation (Nistodana) of eyes of both experimental and control group. That means both the drugs are equally acting on this symptoms.

Table 8: In case of Raag i.e. congestion of eyes

\begin{tabular}{|l|l|l|l|l|l|l|}
\hline \multicolumn{2}{|l|}{ Experimental Group } & \multicolumn{2}{l|}{ Control Group } & S.E & T & P \\
\cline { 1 - 3 } Mean & S.D & Mean & S.D & & & \\
\hline 2.46 & 0.51 & 2.1 & 0.58 & 0.1248 & 2.88 & $\mathrm{P}<0.05$ \\
\hline
\end{tabular}

Here $\mathrm{t}_{\mathrm{cal}}$ is 2.88 and $\mathrm{t}_{\mathrm{tab}}$ is 2 , i.e. $\mathrm{t}_{\mathrm{tab}}<\mathrm{t}_{\mathrm{cal}}$. Hence $\mathrm{t}$-test is significant indicates that the effect of experimental drug is more than that of control drug on Raag i.e. congestion of eyes. 
Table 9: Total Effect of therapy

\begin{tabular}{|l|l|l|l|l|}
\hline Groups & $\begin{array}{l}\text { Cured } \\
\text { Cases }\end{array}$ & $\begin{array}{l}\text { Relieved } \\
\text { Cases }\end{array}$ & $\begin{array}{l}\text { Not } \\
\text { Cured } \\
\text { Cases }\end{array}$ & Total \\
\hline Experimental & 13 & 10 & 7 & 30 \\
\hline Control & 8 & 12 & 10 & 30 \\
\hline Total & 21 & 22 & 17 & 60 \\
\hline
\end{tabular}

$$
\left(\chi 2_{\text {cal }}: 3.53 ; \chi 2_{\text {tab }}: 5.99\right)
$$

Calculated Chi SquareValue $(\chi 2)$ is lower than the Chi Squaretable hence not significant at $5 \%$ level $\left(\chi 2_{\text {cal }}: 3.53 ; \chi 2_{\text {tab }}: 5.99\right)\left(\chi 2_{\text {cal }}>\chi 2_{\text {tab }}\right)$. Thus there is no difference in both the treatments. Both drugs used are equally acting on VatajAbhishyanda w.r.t. allergic conjunctivitis i.e. drug used for trial is as effective as the conventional therapy (control group). But if we take large sample then $\chi 2$ testmay be significant.

(Here $t_{\text {tab }}$ is table value of ' $t$ ', $t_{\text {cal }}$ is calculated value of ' $\mathrm{t}$ ', $\chi 2_{\text {tab }}$ is table value of Chi-square and $\chi 2_{\text {cal }}$ is calculated value of Chi-square.)

\section{Discussion}

The eyes are the most important sensory organ in the body. All out efforts should be made by man to protect the eyes, throughout the period of life. This study was selected to prescribe comparatively cheap and easily available preparation in patient's interest. The Abhishyanda is a disease which we have to treat first in all eye diseases, because it is a prime cause of other eye diseases and leads to various complications.

In Vataj Abhishyanda, Vata is a predominant Dosha and Rasa and Rakta are the Dushyas. The signs and symptoms are purely due to vitiation of Vata Dosha. The various Achakshushya Hetus vitiates Vata Dosha in the Sirasrotas of Urdhwa Jatru region. Then this vitiated Dosha move towards the eye through the eye Sirasrotas confined to the Sira in the eye. If there is Kha-Vaigunya present in the eye i.e. in the Shlaishmik Kala then Syanda is produced which is called as Vataj Netrabhishyanda. Here this Vata vitiation is Swatantra i.e. independent and Kapha and Pitta are the other dependent vitiated Dosha. Vataj Abhishyanda is a disease whose signs and symptoms can be correlated with allergic conjunctivitis.

Triphala is a trio consists of Haritaki, Amalaki and Bibhitaka (8). Sharangdharacharya mentioned that Triphala is a drug of choice for all types of Netrabhishyanda. Acharya Gayadasa quoted in Dalhana commentary that Triphala Ghrita is a Vyadhipratyanik Dravya. Triphala and Ghrita are Chakshushya Dravya i.e. both gives Bala to Chakshurendriya (9). Triphala is believed to have balancing and rejuvenating effect on the three constitutional elements in Ayurveda viz. Vata, Pitta \& Kapha. Ghrita has its lubricating action by Snigdha Guna and also as it is Samskaranuvarti (10) it carries the properties of Triphala and act as a good mediator. Also the topical conventional medicaments available in the market are topical decongestants which when used for a long period actually worsen the symptoms, overuse of topical antihistamines causes dryness and topical steroids overuse can cause elevated intra ocular pressure(IOP), leads to visual damage, increased risk of cataract and clouding of lens that can lead to impairment of vision. These topical drugs costs between 55 to $85 \mathrm{Rs} /-$ which are unaffordable to poor patients, while the trial drug costs only 7.5 to $9 \mathrm{Rs} /-$ (per $10 \mathrm{ml}$ ) including preparation cost which is in patients interest and feasible to the researcher also. So it was decided to instill Triphala Ghrita in Vataj Abhishyanda w.r.t allergic conjunctivitis. Acharya Arundatta was mentioned in his commentary about the Upashaya of disease Vataj Abhishyanda by Snigdha and Ushna Chikitsa (11). Here Ghrita is a Snigdha Dravya and best Vatashamak among the Snehas and by making Triphala Ghrita luke warm we are applying it in conjunctiva so it gives a lubricating and soothing effect in allergic conjunctivitis.

Aschyotan Kriyakalpa was selected for the trial because it was a prime treatment in all types of eye diseases (12). Aschyotan significantly reduces the congestion of eyes, itching, pricking sensation of eyes, burning sensation, lacrimation, etc. also A schyotan can also be given in Samavastha of the eye diseases so the Kriyalkalpa Aschyotan was decided for the trial.

\section{Probable mode of action (cause and effect relationship)}

Acharya Vagbhata stated the mode of action of Aschyotan, as the Aschyotan drug goes in Urdhwajatru i.e. in region above the collar bone, spreads and brings Dosha outside by its Veerya (13). Aschyotan is a Shodhana process [Bahyaparimarjana Chikitsa] when decoctions are used for procedure and it acts as Shamana process when Ghritas are used. Ghrita by its Snigdha Guna pacifies the Ruksha Guna of Vata. Vayu Mahabhuta Pradhana Ruksha Guna in Vataj Abhishyanda was pacified by Aap Mahabhuta Pradhan Snigdha Guna. Snigdha Guna has soothing property and causes moistening of conjunctival mucosa and increases the stability, Bala and Varna. Sheeta and Ruksha Guna together causes the Sangharsha i.e. itching sensation of eyes and increases the vasoconstriction and grittiness feeling in the eyes.

These Gunas were pacified by the lukewarm Ghrita Aschyotan procedure which allows more absorption of drug through the vessels and decreases the symptom. So the parameter of efficacy was fulfilled and experimental group showed results better than he control group. The mucosa of conjunctiva absorbs the drug. So by virtue of Madhur Rasa of the contents in the Triphala Ghrita and the Rasayana property Vata Prashamana occurs. Chakshushya property of Triphala and Ghrita as well as the Jeevaniya property of Godugdha combinely acts and the Vata dosha come to normalcy. The Swantantra (independent) Vata Dosha Dushti pacified by all these properties. So the results observed in experimental and control group are nearly same in Nistodana i.e. irritation and Foreign Body sensation of eyes. Ghrita when instilled in eyes causes some irritation and along with that Triphala has its 
Kashaya Rasa which also responsible for the irritation though the Snigdhatwa of Ghrita overcomes this Kashaya Rasa of Triphala and compensate it.

Fat soluble factors can penetrate Krishnamandalam and Shuklamandalam. So if Snigdha drugs especially Ghrita Kalpana is applied, it penetrates the Mandala so the Laghu, Ruksha Gunas are counter acted. Thus the patients feel relief.

Now coming to the point of allergy, it was nothing but the Asatmya Avastha of the body tissue. Each Dosha has its certain tolerance in the body. Whenever external factors disturb these constitutional elements Dosha vitiates in two ways i.e. Swantatra and Paratantra Dosha Dushti (14). In allergic conjunctivitis Vata is a Swatantra Dosha vitiated by external factors and the Paratantra Dosha are Kapha and Pitta. Histamines can be correlated with Pitta Dosha. So considering this correlation Triphala is a trio of Tridoshahara Prabhava and a fortified combination of Haritaki, Amalaki, Bibhitaki and Ghrita and Godugdha (Cow's Milk) removes the intolerance of excess or vitiated Vata Dosha by acting virtue of its Guna on Vata Dosha. Hence in this study the symptoms itching, Foreign Body and irritation sensation of eyes and congestion of eyes are relieved.

\section{Samprapti bhanga}

The vitiated Dosha are Siranusari and they come in eyes via these Siras (15). Triphala Ghrita when instilled in eyes it breaks the Samprapti of Vataj Abhishyanda, pacify the Vata Dosha and Rakta Dushya. Absorbed more through the Sira, it reaches the circulation and thus acts.

\section{Modern way of action}

Siras are routes of pathogenesis in eyes, so drug absorption is more from these Siras in Aschyotan gives results in the symptoms like congestion of eyes. The herbal compounds given in the forms of infusion and decoction contains varying amount of saponins which increases the permeability of epithelium by reducing the surface tension. Also the drug absorption is directly proportional to the vascularity of absorbing surface. Conjunctiva is a vascular tissue containing arcades of blood vessels. So drug absorption is more and result was good. The Triphala Ghrita is a aqueous suspension where the drug is present as small particle kept suspended in an aqueous medium by a dispersing agent (medicated ghee). Particles do not leaves the eye quickly as solutions which increase the tissue contact time. The Triphala Ghrita absorbs through the conjunctival mucosa, percolates into the palpebral conjunctiva and then into the bulbar conjunctiva and acts as a lubricant also. The viscosity of Ghrita, height from which it is dropped on eye ball, frequency and its duration of instillation, size of the drop and condition of the patient and temperature of Ghrita during procedure are all contributory factors to its absorption and action. In this way Triphala Ghrita acts in allergic eye diseases through the conjunctival route of drug administration (16).

\section{Limitations of the study:}

The limitations of the study are mainly the investigational parameter. The tests regarding the diagnosis of allergic eye diseases are costly like $\operatorname{IgE}$ count in tear, skin prick test. Also the eosinophils to come in smear it need vigorous scraping of conjunctiva. So this thing needs careful as well as skillful efforts. The other tests are performed in big hospitals only. But to diagnose an allergic eye disease these test are used at limited extent and rely more on history. So the eosinophil's parameter was not fulfilled in this study and it remains a challenge for the future researchers in Ayurveda. Another limitation is that the allergic eye disease is a vast topic and it needs a long duration for study perhaps more than three years. So in present study sincere attempt was made to study the disease in least period.

\section{Scope of further study}

Since there is an unduly long communication that we have lost the technical aspect of all the Kriyakalpa and it's our duty now to renovate the science and technology. One can study the complex form of allergic eye diseases like Vernal Keratoconjunctivitis, Atopic Keratoconjunctivitis with the help of other forms of medicines like decoction. Allergy is a disease of present era which caused due to suppressed immunity. The modern medicines has lacuna in this area and so an Ayurvedic doctor can treat this disease according to Dosha Dushya and also can prove it on modern parameter basis. Local therapy along with Panchakarma and systemic medicines may be effective. Further study is necessary for the Brimhana of Ayurvedic science.

\section{Conclusion}

Thus from above study it can be concluded that the trial drug Triphala Ghrita is equally effective as compared to Ketotifen eye drop. However the objective parameter in the above study needs to be further verified by conducting proper investigational methods in allergic conjunctivitis.

\section{Acknoeledgement}

Dr. S.M.Panzade (Guide and H.O.D), Dr. N.A.Khan, Dr. Ashok Vaijwade, Dr.Kalpana Wakode, Dept. of Shalakyatantra, Govt.Ayurved College, Nanded (M.S)

\section{References}

1. Vd. Yadavji Trikamji and Narayan Ram Acharya, Sushruta Samhita Uttartantra 6/5, By Sushruta with Nibandhasngraha Commentry of Shri Dalhanacharya, Varanasi, Choukhamba Sanskrita Sansthan, Edition reprint 2010, P-603.

2. Vd. YadavjiTrikamji and Narayan Ram Acharya, Sushruta Samhita Uttartantra 6/6, By Sushruta with Nibandhasngraha Commentry of Shri Dalhanacharya, Varanasi, Choukhamba Sanskrita Sansthan, Edition reprint 2010, P-603.

3. Albelson $\mathrm{M}$ B, George $\mathrm{M}$ A, Garofalo $\mathrm{C}$. Differential diagnosis of ocular disorders. Ann Allergy 1993; 70(2): P 95-105

4. Vd. Yadavji Trikamji and Narayan Ram Acharya, 
Sushruta Samhita Uttartantra 18/4, By Sushruta , Varanasi, Choukhamba Sanskrita Sansthan, Edition reprint 2010, P-633.

5. Acharya Shri RadhakrushnaParashar, Sharangdhara Samhita Uttartantra 13/20, 4 th edition, Published by Baidyanath Ayurved Bhavan, Year 1961, P-582,583.

6. Vd. Yadavji Trikamji and Narayan Ram Acharya, Sushruta Samhita Uttartantra 9/8, By Sushruta with Dalhana Tika, Varanasi, Choukhamba Sanskrita Sansthan, Edition reprint 2010, P-611.

7. Late Dr. A.M. Kunte, Krishnashastri Navare, Ashtanghrudaya Uttartantra 13/10-11, Sarvangsundar Vyakhya, Varanasi, Choukhamba Orientalia, P-819.

8. Vd. Yadavji Trikamji Acharya, Charaka Samhita Sutrasthana 2/9,10 by Agnivesha, Varanasi, Choukhamba Surbharati Prakashan, Reprint edition 1992, P-24.

9. Prof. K.C. Chunekar, Bhavprakash Haritakyadi Varga 42, 43, Ghrita Varga 1, 2, edited by Late Dr.G.S. Pandey, Varanasi, Choukhamba Bharati Academy, Revised edition 2010, P-12, 758

10. Vd. Yadavaji Trikamaji Acharya, Charakasamhita Sutrasthana 13/13, by Agnivesha, Varanasi, Choukhamba Surbharti Prakashan, Reprint edition 1992, P-82.
11. Late Dr. A.M. Kunte, Krishnashastri Navare, Ashtanghruday Uttartantra 15/1-3, Sarvangsundar Vyakhya, Varanasi ,Choukhamba Orientalia,P-828.

12. Late Dr. A.M. Kunte, Krishnashastri Navare, Ashtanghruday Sutrasthana23/1, Sarvangsundar Vyakhya, Varanasi, Choukhamba Orientalia, P303.

13. Late Dr. A.M. Kunte, Krishnashastri Navare, Ashtanghruday Sutrasthana 23/7, Sarvangsundar Vyahkya, Varanasi, Choukhamba Orientalia, P-304.

14. Late Dr. A.M. Kunte, Krishnashastri Navare, Ashtanghruday Sutrasthana12/59,60, Sarvangsundar Vyakhya, Varanasi, Choukhamba Orientalia, P204,205.

15. Vd. Yadavji Trikamji Acharya, Sushrutasamhita Uttartantra 1/20,21, by Sushruta with Nibandhasangraha Commentry of Shri Dalhanacharya, Published by Pandurang Jawaji, Nirnay Sagar Press, , Edition print 1931, P-539.

16. Prof. Dr.K.S.Dhiman , Shalakyatantra- Kriyakalpa Vidnyan, Ch.9, Varanasi, Published by Choukhamba Vishwabharati, First Edition 2013, P134 to 143 . 